\title{
Long-Term Prospects for the Environmental Profile of Advanced Sugar Cane Ethanol
}

Cinthia R. U. da Silva, ${ }^{* \dagger, \ddagger, \S}$ Henrique Coutinho Junqueira Franco, ${ }^{\ddagger}$ Tassia Lopes Junqueira, ${ }^{\ddagger}$

Lauran van Oers, ${ }^{\S}$ Ester van der Voet, ${ }^{\S}$ and Joaquim E. A. Seabra ${ }^{\dagger, \ddagger}$

${ }^{\dagger}$ Faculdade de Engenharia Mecânica, Unicamp. Rua Mendeleyev 200, Cidade Universitária “Zeferino Vaz”, Campinas, SP, Brazil, $13083-860$

${ }^{\ddagger}$ Brazilian Bioethanol Science and Technology Laboratory (CTBE) - CNPEM - Rua Giuseppe Máximo Scolfaro 10.000, Polo II de Alta Tecnologia, P.O. Box 6170, Campinas, SP, Brazil, 13083-970

${ }^{\S}$ Institute of Environmental Sciences (CML), Leiden University, P.O. Box 9518, 2300 RA Leiden, The Netherlands

Supporting Information

ABSTRACT: This work assessed the environmental impacts of the production and use of $1 \mathrm{MJ}$ of hydrous ethanol (E100) in Brazil in prospective scenarios (2020-2030), considering the deployment of technologies currently under development and better agricultural practices. The life cycle assessment technique was employed using the CML method for the life cycle impact assessment and the Monte Carlo method for the uncertainty analysis. Abiotic depletion, global warming, human toxicity, ecotoxicity, photochemical oxidation, acidification, and eutrophication were the environmental impacts categories analyzed. Results indicate that the proposed improvements

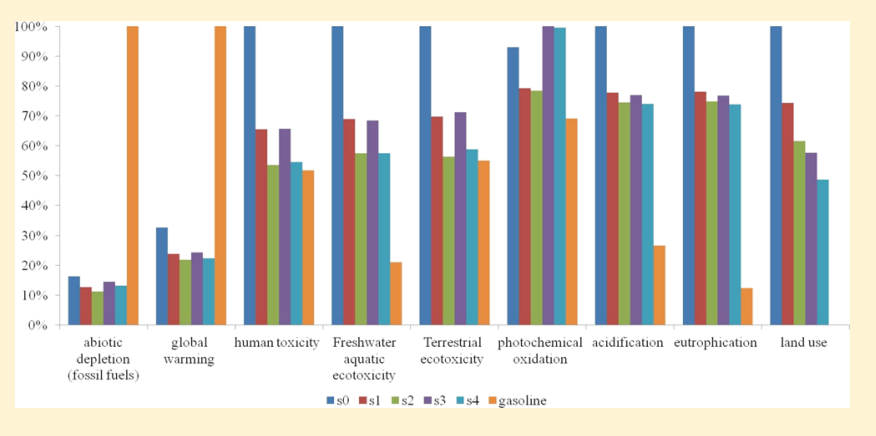
(especially no-til farming-scenarios s2 and s4) would lead to environmental benefits in prospective scenarios compared to the current ethanol production (scenario s0). Combined first and second generation ethanol production (scenarios s3 and s4) would require less agricultural land but would not perform better than the projected first generation ethanol, although the uncertainties are relatively high. The best use of 1 ha of sugar cane was also assessed, considering the displacement of the conventional products by ethanol and electricity. No-til practices combined with the production of first generation ethanol and electricity (scenario s2) would lead to the largest mitigation effects for global warming and abiotic depletion. For the remaining categories, emissions would not be mitigated with the utilization of the sugar cane products. However, this conclusion is sensitive to the displaced electricity sources.

\section{INTRODUCTION}

Bioethanol production has increased worldwide pushed by the need to displace fossil fuels and reduce the emissions of Greenhouse Gases (GHG). In Europe and US, relevant rules were adopted to foster the sustainable use of biofuels, ${ }^{1,2}$ although there are concerns about the possible negative impacts of these mandates on the global ethanol market. ${ }^{3}$ Despite the methodological differences, ${ }^{4}$ both regulations indicate that first generation sugar cane ethanol has a substantial potential to mitigate GHG emissions. Additionally, if managed sustainably, biofuels can help to solve pressing environmental, social, and economic problems. In this sense, cellulosic biofuels and sustainable agriculture are quoted among the long-term "winwin" opportunities for biofuels. ${ }^{5}$

In face of the vast availability of sugar cane residues, ${ }^{6}$ investments on research and development of ethanol from lignocellulosic materials compose the Brazilian efforts to improve the environmental performance of sugar cane ethanol. More specifically, the creation of the Brazilian Bioethanol Science and Technology Laboratory (CTBE) reflects the government support for the development of agricultural and conversion technologies aimed at the sustainable expansion of ethanol production in the country. ${ }^{7,8}$

Some studies have already been published providing information about the projected environmental and economic performance of ethanol production from sugar cane residues in Brazil considering different technological configurations and assumptions. $^{9-14}$ In spite of the relative agreement on the economics, results concerning environmental aspects (GHG emissions) can be controversial, depending on the functional unit adopted and other methodological choices. ${ }^{9,10} \mathrm{~A}$ technoeconomic evaluation favored the biochemical conversion when compared to the thermochemical conversion of bagasse to ethanol, ${ }^{11}$ while another study indicated the importance of the integration of second generation (biochemical route) into

Received: May 27, 2014

Revised: September 12, 2014

Accepted: September 17, 2014

Published: October 2, 2014 
an optimized first generation plant to increase process feasibility, since part of the infrastructure could be shared and bagasse is already available in the plant. ${ }^{12}$ The second generation technology can also benefit from thermal and water integration, with positive implications for the payback time when integrated with sugar production. ${ }^{13}$

Besides the development of second generation ethanol, improvements in the sugar cane cultivation are expected as well. Minimum tillage practices, for instance, have already been introduced in some sugar cane areas, and no-til farming is expected to be in place in the medium-long-term. In this context, CTBE is developing a controlled traffic structure (ETC) to reduce soil compaction and hence reduce the number of required operations for soil preparation and facilitate the introduction of the no-til farming. ${ }^{8}$ Even without considering the use of ETC, Bordonal et al. ${ }^{15}$ already indicate a better performance of the first generation ethanol when minimum tillage practices are used.

These developments are expected to favor the sustainability of sugar cane ethanol, but their environmental benefits are not clear yet. Analyses are thus required to evaluate the environmental gains of the adoption of advanced cultivation practices and conversion technologies (such as ETC and sugar cane residues-to-ethanol) in face of the alternative uses of sugar cane biomass and the incremental developments expected in sugar cane production in the future.

Assuming that such technologies could improve ethanol's environmental profile, this work assessed the environmental impacts of the production and use of $1 \mathrm{MJ}$ of hydrous ethanol in Brazil in prospective scenarios. Comparisons were carried out considering as reference the current life cycle performance of Brazilian sugar cane ethanol and fossil gasoline. In addition to ethanol's life cycle profile, the net environmental benefits of each scenario were also evaluated considering the displacement of the equivalent fossil alternatives of sugar cane bioenergy, i.e. gasoline as a transportation fuel and natural-gas-powered thermoelectricity.

The analysis employed the Life Cycle Assessment (LCA) technique considering eight environmental impacts categories: abiotic resource depletion, global warming, photochemical oxidation, human toxicity, freshwater aquatic ecotoxicity, terrestrial ecotoxicity, acidification, and eutrophication. Landuse requirements for ethanol production were estimated and briefly discussed. Given the uncertainties associated with the projected conditions, an uncertainty analysis was conducted based on the Monte Carlo method. This analysis is expected to support decisions about the best utilization of biomass resources for the maximization of environmental gains.

\section{MATERIALS AND METHODS}

Life Cycle Assessment. The study used the Life Cycle Assessment (LCA) technique to evaluate the ethanol environmental profile for each scenario, considering an attributional well-to-wheels approach. The CML version 3.9, a problem oriented approach, was the method employed in the Life Cycle Impact Assessment (LCIA), ${ }^{16,17}$ covering eight environmental impact categories: abiotic resource depletion (fossil fuels), global warming, photochemical oxidation, human toxicity, freshwater aquatic ecotoxicity, terrestrial ecotoxicity, acidification, and eutrophication. These categories embrace the main emissions in the ethanol life cycle. The CMLCA software $^{18}$ was used to create and link the life cycle processes and to assist in the interpretation phase, including the development of the contribution and uncertainty analyses. The functional unit for the comparative LCAs was $1 \mathrm{MJ}$ of hydrous ethanol, and the allocation method was based on partitioning using energy flows.

In addition to the ethanol's life cycle profile, the best use of 1 ha of sugar cane was also assessed. In this case, the study compared the net environmental benefits of each scenario, taking into consideration the displacement of the conventional products: gasoline and thermoelectricity produced in a natural gas power plant.

The gasoline life cycle inventory was assembled using representative parameters of the Brazilian conditions, ${ }^{19}$ disregarding changes in the supply chain within the timehorizon of this analysis. With respect to the electricity generation in natural gas-fired power plants, the UCTE life cycle inventory from the Ecoinvent database was used. ${ }^{10,20} \mathrm{~A}$ sensitivity analysis was performed to show the impact of two extreme cases, considering that the surplus electricity would displace the average electricity mix in Brazil or electricity from coal-fired power plants, using EcoInvent database for UCTE. ${ }^{20}$ The life cycle inventory of the average electricity was based on an adapted process of the Ecoinvent database ${ }^{20}$ considering the $2011 \mathrm{mix}$ ( $81.7 \%$ hydroelectricity, $6.5 \%$ biomass, $0.5 \%$ wind, $1.4 \%$ coal, $2.5 \%$ fossil oil, $4.6 \%$ natural gas, $2.7 \%$ nuclear $^{21}$ ). For the coal-based electricity, it was assumed the UCTE life cycle inventory from Ecoinvent. ${ }^{20}$

Emissions and removals of biogenic carbon along the process chain were assumed to be synchronized, so they were not taken into account. The land use change (LUC) impacts were not the focus of this work, but the land-use requirements for ethanol production in each scenario were estimated and briefly discussed. In terms of the impacts, it is worth mentioning that the recent sugar cane expansion in Brazil has mostly occurred over pasture land, and the overall effect may actually be of increasing the $\mathrm{C}$ stocks in soil, although large uncertainties exist because of the still lack of information on carbon stocks. $^{22-25}$

For the foreground systems, representative data of Brazilian conditions were collected, while Ecoinvent database was used when data was not available for the background processes. As the analysis considered projected conditions based on the estimations of different specialists, ranges of values were verified and uncertainties exist. A contribution analysis was performed as part of the interpretation phase to subsidize the uncertainty analysis. The uncertainty assessment followed the Monte Carlo method, using 2000 trials. The parameters for the Monte Carlo analysis are in the Supporting Information.

Scenarios Definition and Description. Four prospective scenarios were considered in the analysis, covering two options for bagasse utilization and two different sugar cane production systems, as presented in Table 1 . One scenario (scenario s0)

Table 1. Description of the Prospective Scenarios

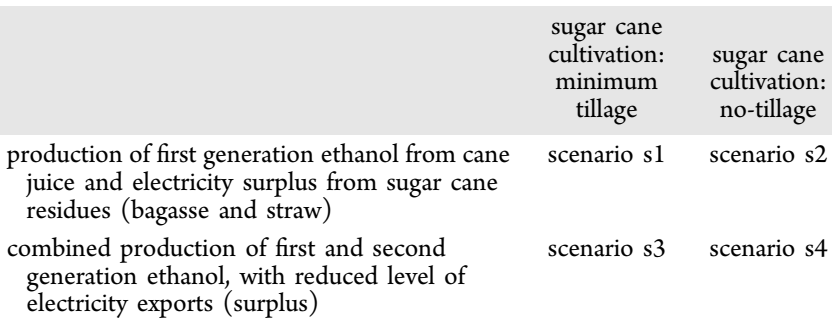


representing the current good practices for sugar cane and ethanol production was also analyzed in order to estimate the environmental improvements enabled by the advanced technologies considered in this work. This scenario assumes the current sugar cane cultivation practices, without preharvesting burning, and production of first generation ethanol from cane juice and electricity surplus from sugar cane residues (bagasse and straw).

Further details about the production pathways are given below, while Figure 1 and Figure 2 show the product systems considered.

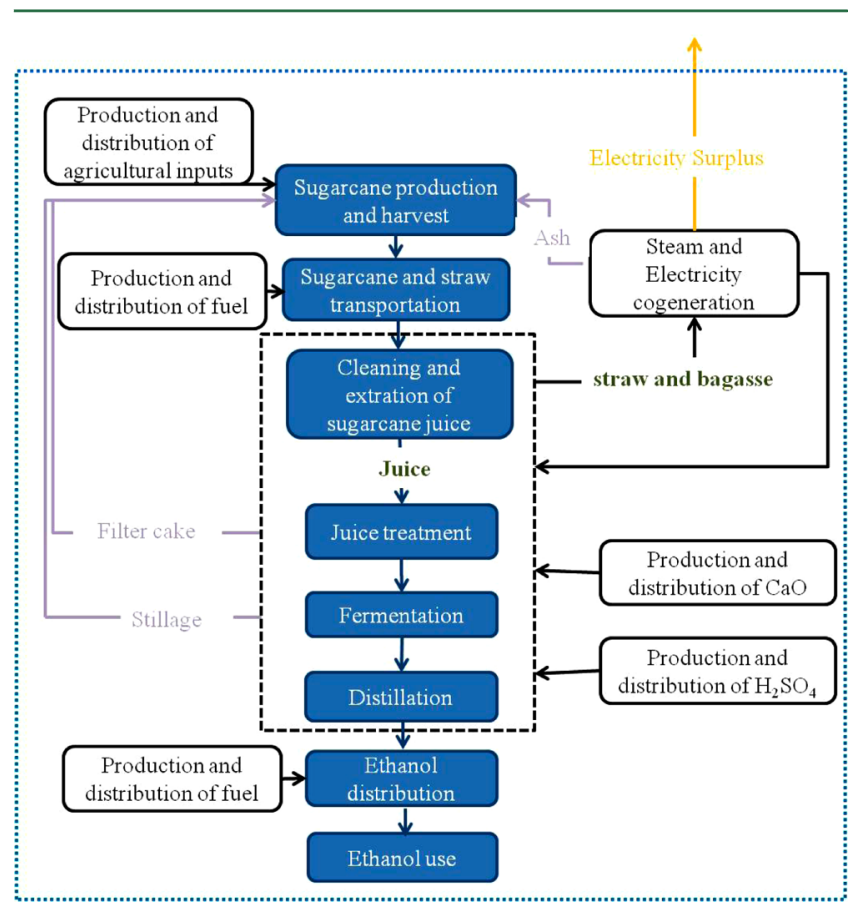

Figure 1. Product system for scenarios s0, s1, and s2.

Sugar Cane Cultivation. An important change expected in sugar cane cultivation in the near future is the complete elimination of the preharvesting burning practice. ${ }^{26}$ In the unburned system, sugar cane harvesting is fully mechanized, and a relevant amount of biomass (sugar cane straw, also called sugar cane trash) becomes available for industrial applications. However, it can also be left on the field aiming at the enhancement of the soil condition, including soil protection and maintenance of soil moisture. The amount of straw to be left on the field and to be recovered for industrial applications should be defined according to the soil properties of each farm, observing the expected agricultural and industrial benefits from biomass utilization. In this study, it was assumed for the prospective scenarios that $50 \%$ of the straw (i.e., $70 \mathrm{~kg}_{\text {dry }} / \mathrm{t}$ cane) would be left on the field, and the remaining 50\% would be collected for industrial use. Given that part of the residues would remain on the field, reduced tillage practices could be adopted.

In the scenario $\mathrm{s} 0$, it was assumed that all the unburned straw is left on the field, under the conventional sugar cane cultivation practices. ${ }^{27}$ In scenarios s1 and s3, minimum tillage is adopted, which eliminates some operations (currently in practice) for soil preparation due to the protection promoted by the straw blanket. Sugar cane harvesting in these scenarios is performed by conventional harvesters. Scenarios s2 and s4, on the other hand, assume the implementation of the low impact mechanization to enable the no-til farming. In this system, sugar cane harvesting is performed by the Controlled Traffic Structure (ETC), which is able to prevent soil compaction, thus eliminating the need for soil preparation operations. ${ }^{8,28,29}$ This is possible because the wheels of the equipment run along permanent, georeferenced tracks (spaced $9 \mathrm{~m}$ apart). This system reduces the traffic of agricultural implements in the cane fields from $60 \%$ (current mechanization) to less than $10 \%$ of the planted area. ${ }^{8}$ Due to the conservationist management practices, the projected gains in sugar cane productivity are expected to be higher in scenarios $\mathrm{s} 2$ and s4, compared to those in scenarios s1 and s3, because ETC would be able to maintain the productivity of the ratoon cane. In the same way, sugar cane productivity is expected to be higher in scenarios s1 and s3, compared to s0. In terms of sugar cane quality (sugar content), no differences are expected between the scenarios, but a higher Total Recoverable Sugar content is expected in the future (160 $\mathrm{kg} / \mathrm{t}$ ) which will allow a higher ethanol yield.

Another improvement assumed for the prospective scenarios was the stillage concentration (1/4 of the initial volume), which would favor the logistics of stillage distribution, allowing its application as fertilizer in the whole sugar cane field. It was assumed that the concentrated stillage has the same nutrients than the conventional stillage but in a smaller water volume (i.e., higher concentration). Stillage from second generation ethanol, however, is assumed to be rather poor in nutrients, so basically all nutrients available are related to the stillage produced from sugar cane juice processing (first generation ethanol). The environmental legislation about stillage application on the field was observed in the calculation. ${ }^{30}$ Because of the improved production practices and better use of the residues from ethanol production, it is expected that sugar cane cultivation in the future will require less mineral phosphorus and no potassium.

As the product systems represent a future situation (20202030), parameters for the foreground systems were defined based on the opinions of experts on sugar cane production and transportation in Brazil. These projected parameters fed spreadsheet models (Canasoft spreadsheet model, developed by Technological Assessment Program at CTBE) dedicated to the estimation of the total inputs and outputs from sugar cane production and transportation from the field to the mill for each scenario.

Sugar Cane Transportation. The transportation of sugar cane from the field to the mill is performed by trucks with different payload capacities. In this work it was assumed that $100 \%$ of the sugar cane will be transported by turnpike doubles. The uncertainty analysis takes into account the use of the other types of trucks.

Ethanol Production. In the last decades ethanol distilleries in Brazil have experienced a considerable improvement in terms of the overall sugar conversion efficiency. ${ }^{31}$ For the future, however, little room has been left for further advances. Still, significant progress is expected regarding the energy balance of the mill and the utilization of the sugar cane residues. Today, ethanol production in Brazil is self-sufficient in energy as the cogeneration plant provides all the steam and electricity required by the process using bagasse as fuel. In addition, many mills are already able to export electricity to the grid-e.g., $53.2 \%$ of mills are connected to the grid in São Paulo State. ${ }^{32}$ All green field (and several brown field) units are equipped with high pressure cogeneration systems (e.g., 68 bar) enabling 


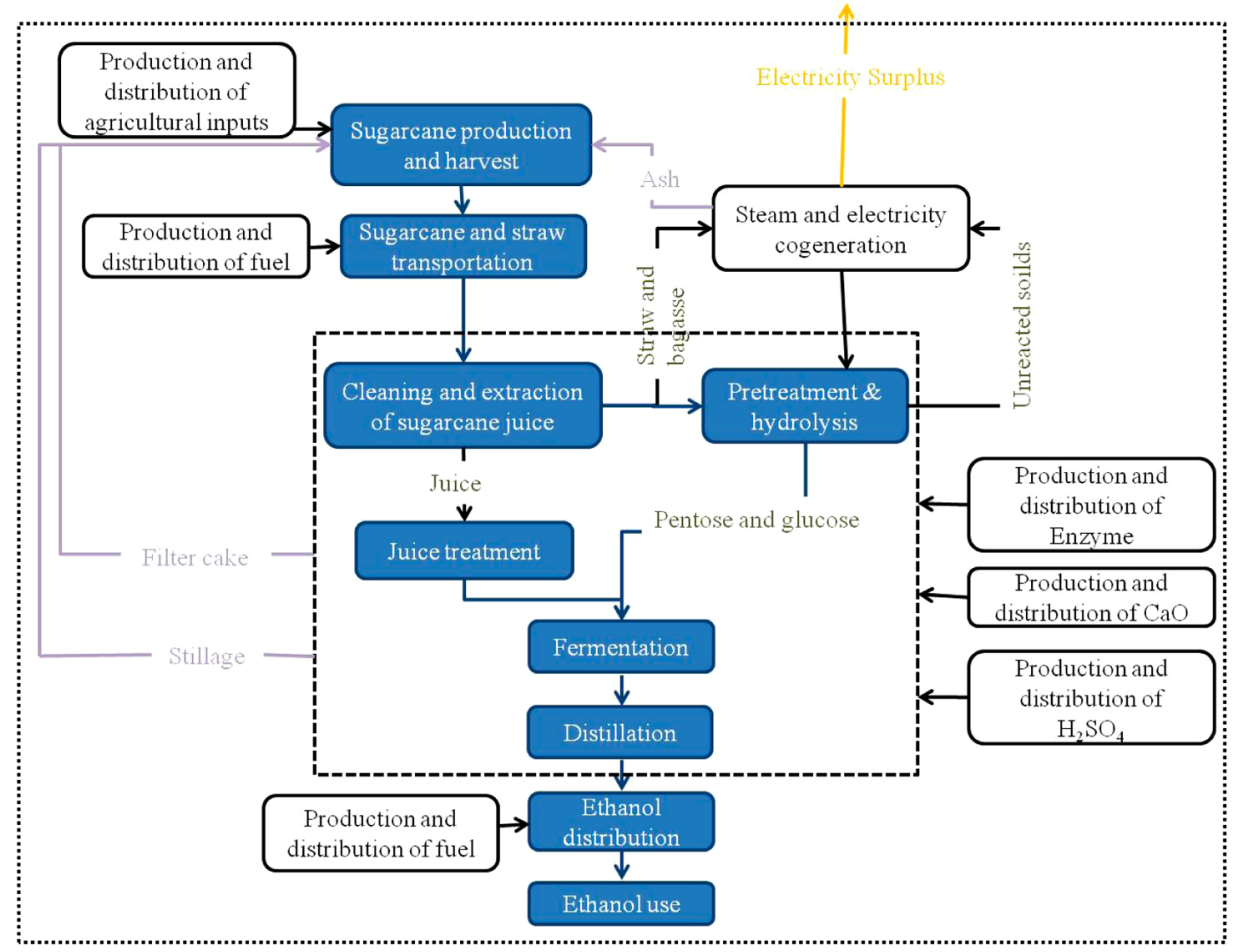

Figure 2. Product system for scenarios $\mathrm{s} 3$ and $\mathrm{s} 4$.

Table 2. Basic Data Related to Sugarcane Production and Processing and Ethanol Distribution

\begin{tabular}{|c|c|c|c|c|c|c|}
\hline \multirow[b]{2}{*}{ item } & \multirow[b]{2}{*}{ unit } & \multicolumn{5}{|c|}{ scenarios } \\
\hline & & $\mathrm{s} 0^{a}$ & s1 & s2 & s3 & s4 \\
\hline cane productivity & $\mathrm{t}$ cane $\mathrm{ha}^{-1}$ & 83.1 & 110 & 132 & 110 & 132 \\
\hline straw (dry basis) ${ }^{b}$ & $\%$ cane stalks & 14.0 & 14.0 & 14.0 & 14.0 & 14.0 \\
\hline sugar cane preharvesting burning & $\%$ area & 0.0 & 0.0 & 0.0 & 0.0 & 0.0 \\
\hline mechanized harvesting & $\%$ area & 100.0 & 100.0 & 100.0 & 100.0 & 100.0 \\
\hline diesel consumption & $\mathrm{L} \mathrm{ha}^{-1}$ & 161.4 & 131.0 & 74.7 & 131.0 & 74.7 \\
\hline straw sent to the mill & $\%$ & 0.0 & 50.0 & 50.0 & 50.0 & 50.0 \\
\hline sugar cane transportation by turnpike doubles ${ }^{c}$ & $\%$ & 100.0 & 100.0 & 100.0 & 100.0 & 100.0 \\
\hline sugar cane TRS & $\mathrm{kg} \mathrm{t}^{-1}$ cane & 140.0 & 160.0 & 160.0 & 160.0 & 160.0 \\
\hline ethanol yield ${ }^{d}$ & $\mathrm{~kg} \mathrm{t}^{-1}$ cane & 68.1 & 75.8 & 75.8 & 96.1 & 96.1 \\
\hline electricity surplus ${ }^{e}$ & $\mathrm{kWh} \mathrm{kg}^{-1} \mathrm{EtOH}$ & 1.2 & 2.6 & 2.6 & 1.1 & 1.1 \\
\hline mill capacity & Mt year ${ }^{-1}$ & 2.0 & 3.0 & 3.0 & 4.0 & 4.0 \\
\hline ethanol distribution-truck $f$ & $\%$ & 100.0 & 80.0 & 80.0 & 80.0 & 80.0 \\
\hline ethanol distribution-pipeline & $\%$ & 0.0 & 20.0 & 20.0 & 20.0 & 20.0 \\
\hline
\end{tabular}

${ }^{a}$ Based on ref $27 .{ }^{b}$ Reference $42 .{ }^{c}$ Distance from the field to the mill: $25.1 \mathrm{~km}$ (scenario s0), $26.6 \mathrm{~km}$ (future scenarios). ${ }^{d}$ Lower heating value: 24.8 MJ EtOH-1. ${ }^{e} 3.6 \mathrm{MJ} \mathrm{kWh}{ }^{-1} .{ }^{f}$ Average distance of $340 \mathrm{~km} .{ }^{41}$

electricity exports greater than $60 \mathrm{kWh} / \mathrm{t}$ of cane using only bagasse as fuel, while the implementation and progress of cane straw recovery may practically double power exports. ${ }^{32-34}$

In this study, these developments were taken into account in all prospective scenarios. Basically, it was considered the adoption of the following equipment/configurations: (i) electrical engines instead of steam turbines as mechanical drivers; (ii) juice extraction with diffusers; (iii) high pressure/ temperature cogeneration systems; (iv) stillage concentration. Stillage concentration was carried out considering the integration to distillation columns, ${ }^{35}$ using a series of evaporators (multiple effect evaporation - MEE) operating below atmospheric pressure, which allows a temperature difference between MEE and distillation columns. In this work, a 5-stage evaporation system was considered, as commonly used in sugar cane mills. The low-grade heat from the rectification column condenser, which condensates the hydrous ethanol, was used as energy source for raising steam. Thus, it was possible to concentrate stillage without increasing the energy demand.

Additionally, it was considered the reduction of the process steam consumption related to the first generation ethanol production and the use of straw as supplementary fuel to bagasse. For scenarios s1 and s2, these improvements lead to lower energy consumption, higher power generation, and, consequently, higher electricity surplus. For scenarios s3 and s4, they allow the utilization of more bagasse for biochemical conversion, while keeping some potential to export electricity.

In scenarios s3 and s4, the production of first and second generation ethanol takes place in an integrated plant. As 


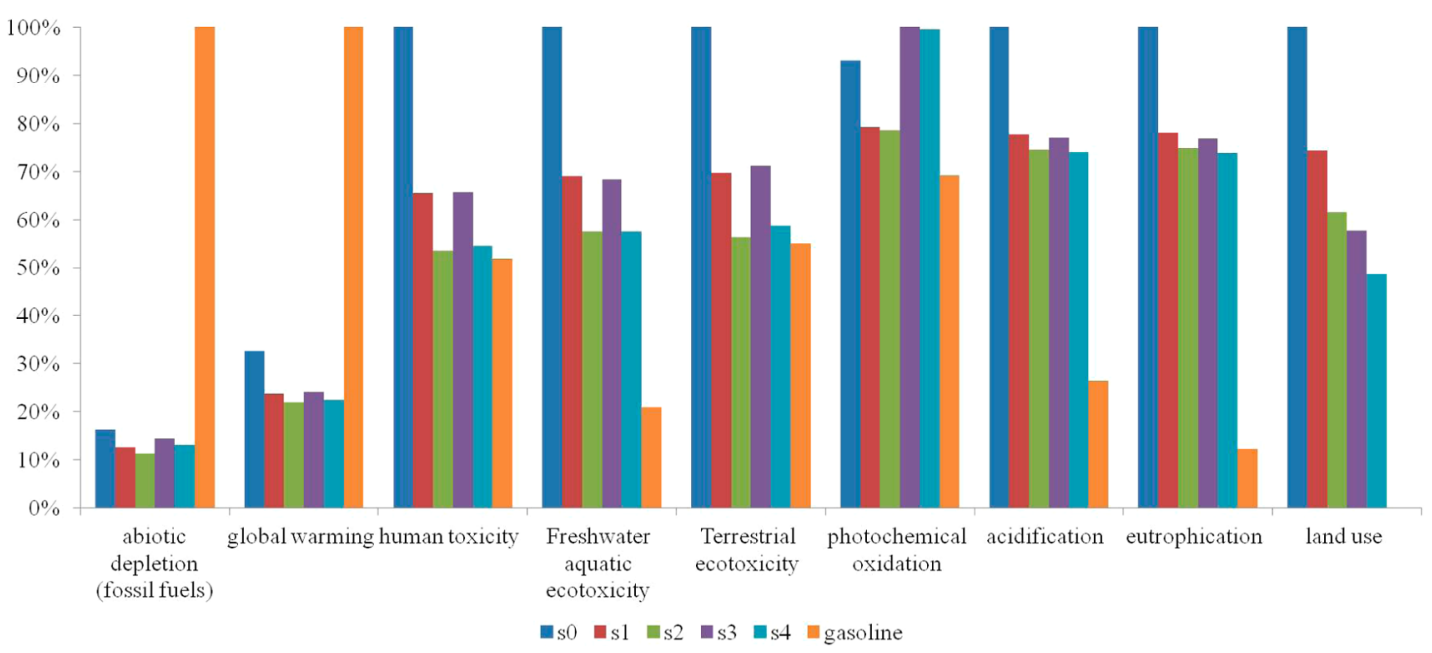

Figure 3. Comparative environmental impact indicators of the different scenarios (1 MJ as functional unit).

illustrated in Figure 2, after the pretreatment (with steam explosion) and the enzymatic hydrolysis, the unreacted solids are sent to the cogeneration plant, while the hydrolyzed liquor is mixed with the sugar cane juice. With such configuration, concentration, fermentation, and distillation operations are shared between first and second generation ethanol processes. ${ }^{12}$ It was assumed that both pentoses and hexoses in the hydrolyzed liquor would be fermented into ethanol.

Data related to sugar cane processing were obtained from simulations using Aspen Plus software, ${ }^{12,33}$ taking into account the technological improvements described above. Data related to enzyme production (for enzymatic hydrolysis) were estimated from the literature. ${ }^{36,37}$ Data for sugar cane bagasse boiler emissions was retrieved from the GREET model ${ }^{38}$ since modern boilers assumed in this work are expected to emit less pollutants than the current ones. ${ }^{39}$ The use of capital goods (buildings and equipment) was estimated from an ethanol distillery that processes $2 \mathrm{Mt}$ of sugar cane per year. ${ }^{40}$ For all cases, the lifetime of the ethanol plant was assumed to be 30 years.

Ethanol Distribution. This study assumed that ethanol would be produced and used in Brazil. For all scenarios, it was considered that ethanol would be distributed via pipeline and trucks. ${ }^{41}$

Ethanol Use. It was considered the use of hydrous ethanol as neat fuel in spark ignition engines. ${ }^{27}$

Table 2 summarizes the basic data for ethanol LCA modeling. Parameters collected from the interviews with specialists and those used for hydrous ethanol production simulation are available in the Supporting Information along with all the remaining data used for the LCA modeling.

\section{RESULTS AND DISCUSSION}

Sugar Cane Ethanol LCA. The comparison between the prospective scenarios and the current scenario $(\mathrm{s} 0)$ indicates that the technological improvements considered here would contribute to decrease the environmental impacts in all categories analyzed, except photochemical oxidation in scenarios s3 and s4. Results for each scenario, including gasoline, are shown in Figure 3, while the complete Life Cycle Inventories are available in the Supporting Information.

The main reasons for the environmental improvement of the prospective scenarios in comparison to the current scenario (s0) are (i) sugar cane cultivation practices, with higher sugar cane productivity and lower diesel demand for agricultural operations, as presented in Table 2; (ii) lower use of mineral fertilizers, once prospective scenarios use stillage concentration, allowing its application in the whole sugar cane area; (iii) lower use of pesticides per tonne of cane, since the application per area are expected to be maintained, along with more biological control; (iv) higher ethanol yield, because of the expected increase in sugar cane's sugar content in the prospective scenarios; (v) higher electricity surplus, because of the straw collection for power generation.

Compared to gasoline, ethanol in all scenarios features smaller impacts in the global impact categories abiotic depletion and global warming. Gasoline, on the other hand, performs better with respect to the remaining, regional impact categories (although this cannot be extrapolated to categories other than those studied here). In this sense, it is interesting to note the concentrated production of large volumes of gasoline in oil refineries compared to the scattered production of ethanol in sugar cane mills, which could represent an environmental concern depending on the local conditions. However, such analysis is beyond the scope of this study, and the conclusion also depends upon the subjective political weighting of the different environmental problems.

Among the prospective scenarios, s2 and s4 feature the smallest environmental impacts. This is due to the ETC use associated with the no-tillage practices, which would enable higher sugar cane productivities. Such results suggest the relevance of advanced farming technologies for enhancing ethanol's environmental profile. The reduced use of diesel in agricultural operations is another reason for the comparative advantage of scenarios s2 and s4. ETC is expected to consume less diesel than the conventional harvester in good part because of the permanent tracks. Besides, sugar cane harvesting with ETC would prevent some soil preparation operations before planting. Because of these aspects, in scenarios s2 and s4, sugar cane farming is responsible for less than one-fourth of the total ethanol's life cycle diesel consumption, while in scenarios s1 and s3, the diesel requirements for farming, sugar cane transportation, and ethanol distribution are approximately the same.

Regarding the technology for ethanol production, scenario s2 (first generation) is the most favorable and scenario s3 (second generation) is the less favorable. Since less electricity surplus is 

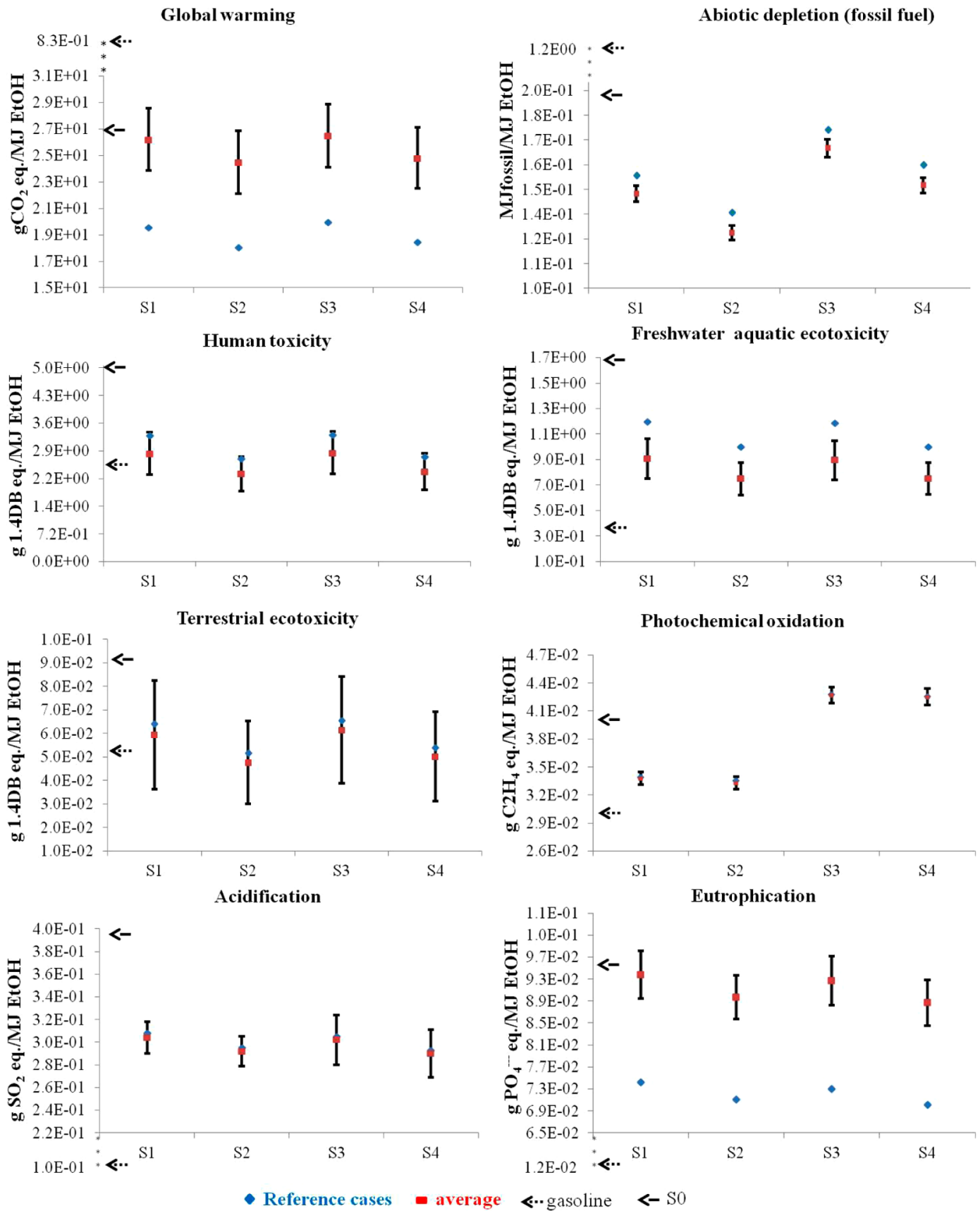

Figure 4. Uncertainty analysis. Error bars represent two standard deviations $(2 \sigma)$.

cogenerated, higher environmental load is allocated to ethanol. Also, inputs associated with the second generation ethanol production contribute to the best results of first generation ethanol. The exceptions are acidification and eutrophication, which are smaller in scenarios s3 and s4 than, respectively, in scenarios $\mathrm{s} 1$ and $\mathrm{s} 2$. This is due to NOx emission associated with biomass combustion in the cogeneration plant, so these impacts are higher in those scenarios featuring greater fuel consumption (thus greater electricity surpluses).

The land-use requirement would be smaller in scenario s4 due to the higher sugar cane productivity and ethanol yield. Despite the worst performance among the prospective scenarios, scenario s1 would still be better than scenario s0 since higher sugar cane productivity is expected with the minimum tillage practices as well as higher electricity surplus because of the recovered straw. It is also possible to see that the second generation technology could contribute to decrease land use more than better practices for sugar cane production.

The contribution analysis (illustrated in the Supporting Information) indicates that carbon dioxide emissions associated with diesel consumption for sugar cane transportation and ethanol distribution are the most relevant to global warming, with significant contributions from $\mathrm{N}_{2} \mathrm{O}$ emissions related to nitrogen fertilizers. For acidification and eutrophication, ammonia emissions from nitrogen fertilizers are the most relevant.

Carbofuran and diuron, used as nematicide and inseticide, are the main contributors to human toxicity and ecotoxicity (freshwater and soil toxicity). As indicated before, the lesser use of pesticides per ton of sugar cane, in comparison to the 


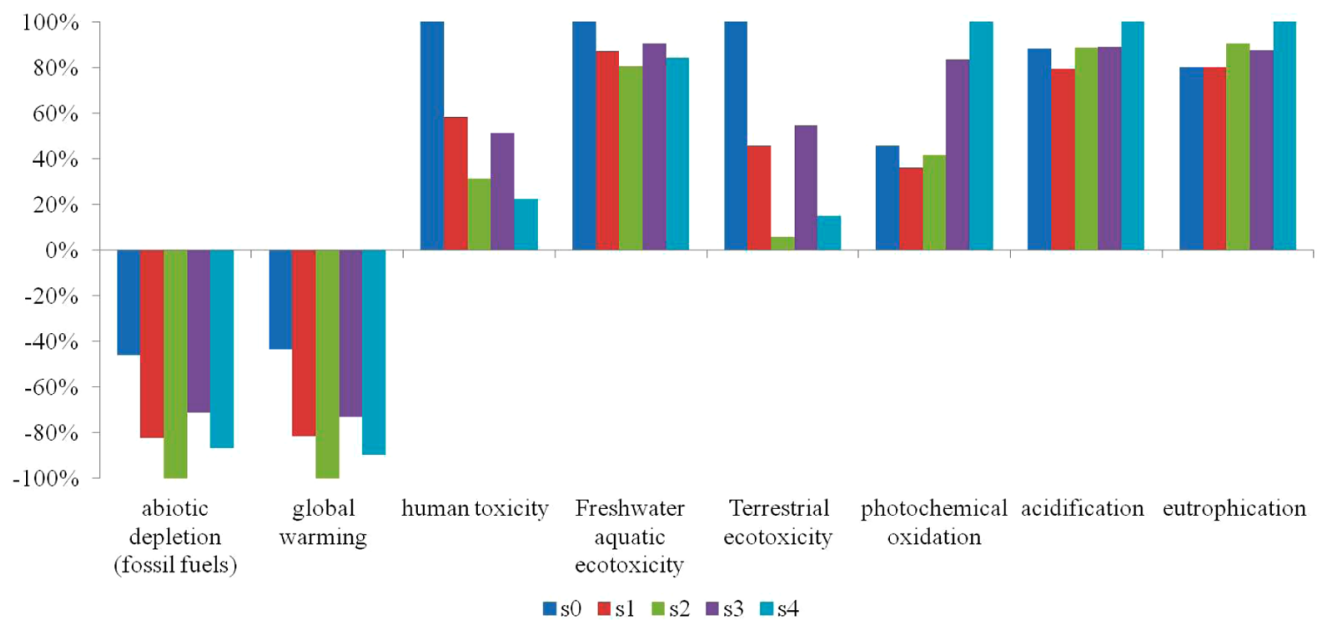

Figure 5. Normalized net environmental impacts related to products from 1 ha of sugar cane.

conventional production, justifies the lower impacts related to those categories. So the replacement of those chemicals composes an important strategy for future mitigation of ethanol's environmental impacts.

$\mathrm{NO}_{x}$ emissions associated with bagasse combustion represent a significant portion of the impact on acidification and eutrophication in scenarios s1 and s2. Those emissions are smaller in scenarios where second generation ethanol is produced (s3 and s4). It must be noted, however, that boiler emissions were estimated based on emission factors obtained from the literature and may not represent the reality of the Brazilian sugar cane sector in the future (though they are lower than to the current limits established by the Brazilian legislation, which may be altered within the time horizon considered in this work).

Scenarios s3 and s4 have a higher impact on photochemical oxidation due to ethanol emissions to air related to the sugar consumed for enzyme production. As sugar is coproduced with ethanol in sugar cane mills, part of the ethanol emissions has been allocated to sugar (allocation by energy content). This is a conservative approach once there are no ethanol emissions associated with sugar production; consequently, photochemical oxidation results for scenarios s3 and s4 are actually overestimated.

As shown in Figure 4, the results are relatively uncertain for most of the impact categories analyzed, which makes the comparative performance analysis less clear. For some categories the average and the reference case are considerably different. The uncertainty regarding global warming and eutrophication is related to $\mathrm{N}_{2} \mathrm{O}$ emissions due to urea application on the field. As pointed out before, the $\mathrm{N}_{2} \mathrm{O}$ emissions have significant impact on global warming, and for the reference cases the emission factor is smaller than the average from the assumed probability density function. $\mathrm{CO}_{2}$ emissions due to diesel use for sugar cane transportation also impact significantly global warming, and for the reference cases the distance considered was smaller than for the average. For human toxicity and ecotoxicity, on the other hand, the reference cases are higher than the averages because of the application of carbofuran and higher use of diuron.

Results for photochemical oxidation are much less uncertain because ethanol emissions from during ethanol distillation were not included among the random variables. It is important to highlight that the uncertainty analysis was mostly based on uncertain variables related to sugar cane production and transportation, in addition to ethanol yield.

The Best Use of 1 ha of Sugar Cane. The normalized results of the net environmental benefits considering the displacement of conventional products by renewable products from one hectare of sugar cane (ethanol and electricity) are presented in Figure 5 (further details are available in the Supporting Information). Negative values in the figure indicate that the environmental impacts would be mitigated with the utilization of sugar cane products.

All scenarios have potential to mitigate global warming and abiotic depletion (fossil fuel), but scenario s2 has the highest potential, followed by scenario s4. For the other impact categories, however, benefits would not be verified. Scenario s1 would have lesser impacts on photochemical oxidation, acidification, and eutrophication; on the other hand, scenario s1 has smaller potential to mitigate abiotic depletion (fossil fuel) and global warming than scenarios s2 and s4.

These results are sensitive not only to the environmental profile of the sugar cane products but also to the displaced products. The sensitivity analysis (given in the Supporting Information) indicates that the electricity source displaced by the electricity surplus from the mill has a major influence on the net benefit of the scenarios. For instance, scenario s4 would lead to greater benefits concerning abiotic depletion (fossil fuel) and global warming instead of s2 in case national average electricity mix was displaced. This is due to the smaller environmental impacts associated with the average electricity from the grid (mostly hydro) compared to electricity generation in natural gas-fired power plants.

Regarding the other impact categories, the comparative performance among the scenarios is not altered according to the electricity source. However, the displacement of electricity generation in coal-fired power plants or average mix electricity could contribute to decrease impacts on human toxicity, ecotoxicity, and photochemical oxidation. Impacts on acidification and eutrophication are higher when average electricity from the grid is displaced. For all categories considered, impacts would be smaller if electricity generation in coal-fired power plants were displaced.

Combining all these elements, it is possible to say that the technological progress expected for the sugar cane industry will likely improve ethanol's environmental profile and the net environmental benefits promoted by the sugar cane products. 
Ethanol would especially benefit from the proposed advances in sugar cane farming, even more than the higher yields enabled by the second generation technology. The industry should therefore pursue those developments, also because they will probably lead to economic gains in the future. However, none of these technologies are commercially mature yet, and significant demonstration efforts are still needed before we have a clear indication about their technical and economic performance at large scales in Brazil.

\section{ASSOCIATED CONTENT}

\section{S Supporting Information}

Detailed data used for each prospective scenario and for uncertainty analysis as well as additional results. This material is available free of charge via the Internet at http://pubs.acs.org.

\section{AUTHOR INFORMATION}

\section{Corresponding Author}

*Phone: 55193521 3284. Fax: +55 193289 3722. E-mail: cinthinha_r@yahoo.com.br.

\section{Notes}

The authors declare no competing financial interest.

\section{ACKNOWLEDGMENTS}

This work benefited from the financial support of Conselho Nacional de Desenvolvimento Científico e Tecnológico (CNPq-process no. 142565/2009-1) and Coordenação de Aperfeiçoamento de Pessoal de Nivel Superior (CAPES process BEX: 6023/11-8). Cinthia da Silva thankfully acknowledges the financial support. The authors gratefully acknowledge the attention of the specialists interviewed.

\section{REFERENCES}

(1) United States Environmental Protection Agency (EPA). Renewable Fuel Standard Program (RFS2) Regulatory Impact Analysis. EPA-420-R-10-006. February, 2010.

(2) EU RED - European Renewable Energy Directive. Directive 2009/28/EC of the European Parliament and of the Council of 23 April 2009 on the promotion of the use of energy from renewable sources and amending and subsequently repealing Directives 2001/ $77 / \mathrm{EC}$ and 2003/30/EC. Official Journal of the European Union. 5.6.2009.

(3) Souza, R. R.; Schaeffer, R.; Meira, I. Can new legislation in importing countries represent new barriers to the development of an international ethanol market? Energy Policy 2011, 39 (6), 3154-3162.

(4) Khatiwada, D.; Seabra, J.; Silveira, S.; Walter, A. Accounting greenhouse gas emissions in the life cycle of Brazilian sugarcane bioethanol: Methodological references in European and American regulations. Energy Policy. 2012, 47, 384-397.

(5) Dale, B. E.; Anderson, J. E.; Brown, R. C.; Csonka, S.; Dale, V. H.; Herwick, G.; Jackson, R. D.; Jordan, N.; Kaffka, S.; Kline, K. L.; Lynd, L. R.; Malmstrom, C.; Ong, R. G.; Richard, T. L.; Taylor, C.; Wang, M. Q. Take a closer look: Biofuels can support environmental, economic and social goals. Environ. Sci. Technol. 2014, 48, 7200-7203.

(6) Foster-Carneiro, T.; Berni, M. D.; Dorileo, I. L.; Rostagno, M. A. Biorefinery study of availability of agriculture residues and wastes for integrated biorefineries in Brazil. Resour., Conserv. Recycl. 2013, 77, 7888.

(7) Nyko, D.; Garcia, J. L. F.; Milanez, A. Y.; Dunham, F. B. A corrida tecnológica pelos biocombustiveis de segunda geração: uma perspectiva comparada. Biocombustiveis BNDES Setorial, 2011, 32. http://www.bndes.gov.br/SiteBNDES/export/sites/default/bndes pt/Galerias/Arquivos/conhecimento/bnset/set32101.pdf (accessed Sept 20, 2014).
(8) CTBE - Brazilian Bioethanol Science and Technology Laboratory Website. www.ctbe.org.br (accessed Sept 20, 2014).

(9) Luo, L.; van der Voet, E.; Huppes, G. Life cycle assessment and life cycle costing of bioethanol from sugarcane in Brazil. Renewable Sustainable Energy Rev. 2009, 13, 1613-1619.

(10) Seabra, J. E. A.; Macedo, I. C. Comparative analysis for power generation and ethanol production from sugarcane residual biomass in Brazil. Energy Policy 2011, 39, 421-428.

(11) Seabra, J. E. A.; Tao, L.; Chum, H. L.; Macedo, I. C. A technoeconomic evaluation of the effects of centralized cellulosic ethanol and co-products refinery options with sugarcane mill clustering. Biomass Bioenergy 2010, 34 (8), 1065-1078.

(12) Dias, M. O. S.; Junqueira, T. L.; Cavalett, O.; Cunha, M. P.; Jesus, C. D. F.; Rossell, C. E. V.; Filho, R. M.; Bonomi, A. Integrated versus stand-alone second generation ethanol production from sugarcane bagasse and trash. Bioresour. Technol. 2012, 103 (1), 152161.

(13) Albarelli, J. Q.; Ensinas, A. V.; Silva, M. A. Product diversification to enhance economic viability of second generation ethanol production in Brazil: The case of the sugar and ethanol joint production. Chem. Eng. Res. Des. 2014, 92, 1470-1481.

(14) Raele, R.; Boaventura, J. M. G.; Fischmann, A. A.; Sarturi, G. Scenarios for the second generation ethanol in Brazil. Technol. Forecasting Social Change 2014, 87, 205-223.

(15) Bordonal, R. O.; Figueiredo, E. B.; Scala, N. J. R. Greenhouse gas balance due to the conversion of sugarcane areas from burned to green harvest, considering other conservationist management practices. Global Change Biol. Bioenergy 2012, 4, 846-858.

(16) Handbook on Life cycle assessment - An operational guide to the ISO standards; Guinée, J., Ed.; Kluwer Academic Publishers: 2002; Vol. 7, ISBN: 1-4020-0228-9.

(17) CML-IA spreadsheet, version 3.9. http://www.cml.leiden.edu/ software/data-cmlia.html (accessed Sept 20, 2014).

(18) CMLCA Software (2012). http://www.cmlca.eu/cmlca52beta. zip (accessed Sept 20, 2014).

(19) Chagas, M. F.; Cavalett, O.; Silva, C. R. U.; Seabra, J. E. A.; Bonomi, A. Adaptação de Inventário de Ciclo de Vida da cadeia produtiva do etanol de cana-de-açúcar no Brasil. III Congresso Brasileiro em Gestão do Ciclo de Vida de Produtos e Serviços. 2012.

(20) Swiss Centre for Life Cycle Inventories. Ecoinvent database, Version 2.0. http:www.ecoinvent.ch/ (accessed Sept 20, 2014).

(21) Balanço Energético Nacional 2012 - Ano base 2011. Brazil: Empresa de Pesquisa Energética. Rio de Janeiro: EPE, 2012. https:// ben.epe.gov.br/downloads/Relatorio_Final_BEN_2012.pdf (accessed Sept 20, 2014).

(22) Macedo, I. C.; Seabra, J. E. A. Mitigação of GHG emissions using sugarcane bioethanol. In Sugarcane Ethanol: Contributions to climate change mitigation and the environment; Zuurbier, P., Van de Vooren, J., Eds.; Wageningen Academic Publishers: The Netherlands, 2008; pp 95-111.

(23) Nassar, A. M.; Rudorff, B. F. T.; Antoniazzi, L. B.; Aguiar, D. A.; Bacchi, M. R. P.; Adami, M. Prospects of the sugarcane expansion in Brazil: impacts on direct and indirect land use changes. In Sugarcane Ethanol: Contributions to climate change mitigation and the environment; Zuurbier, P., Van de Vooren, J., Eds.; Wageningen Academic Publishers: The Netherlands, 2008; pp 66-93.

(24) Walter, A.; Dolzan, P.; Quilodran, O.; De Oliveira, J. G.; Da Silva, C.; Piacente, F.; Sergerstedt, A. Sustainability assessment of bioethanol production in Brazil considering land use change, GHG emissions and socio-economic aspects. Energy Policy 2010, 39 (10), 5703-5716.

(25) Adami, M.; Rudorff, B. F. T.; Freitas, R. M.; Aguiar, D. A.; Sugawara, L. M.; Mello, M. P. Remote sensing time series to evaluate direct land use change of recent expanded sugarcane crop in Brazil. Sustainability 2012, 4, 574-585.

(26) Dispõe sobre a eliminação gradativa da queima da palha da canade-açúcar e dá providências correlatas. Lei Estadual no. 11.241/2002. HTTP://www.sigam.ambiente.sp.gov.br/sigam2/Repositorio/24/ 
Documentos/Lei\%20Estadual_11241_2002.pdf (accessed Sept 20, 2014).

(27) Cavalett, O.; Chagas, M. F.; Seabra, J. E. A.; Bonomi, A. Comparative LCA of ethanol versus gasoline in Brazil using different LCIA methods. Int. J. Life Cycle Assess. 2013, 18, 647-658.

(28) Hamza, M. A.; Anderson, W. K. Soil compaction in cropping systems: A review of the nature. Causes and possible solutions. Soil Tillage Res. 2005, 82 (2), 121-145.

(29) Bioetanol combustivel: uma oportunidade para o Brasil. Centro de Gestão e Estudos Estratégicos. Brasilia, DF, 2009. http://www.cgee. org.br/publicacoes/bioetanol2_2009.php (accessed Sept 20, 2014).

(30) São Paulo State. CETESB (Companhia de Tecnologia de Saneamento Ambiental). (P4.231. Dez/2006).

(31) Leal, M. R. L. V.; Walter, A. S.; Seabra, J. E. A. Sugarcane as an energy source. Biomass Convers. Biorefin. 2013, 3 (1), 17-26.

(32) Filho, A. B. A Geração Termoelétrica com a Queima do Bagaço de Cana-de-Açúcar no Brasil - Análise do Desempenho da Safra 2009-2010. CONAB (Companhia Nacional de Abastecimento). 2011. http://www.conab.gov.br/OlalaCMS/uploads/arquivos/11_05_05_ 15 45_40_geracao_termo_baixa_res..pdf (accessed Sept 20, 2014).

(33) Dias, M. O. S.; Modesto, M.; Ensinas, A. V.; Nebra, A. S.; Maciel Filho, R.; Rossell, C. E. V. Improving bioethanol production from sugarcane: evaluation of distillation, thermal integration and cogeneration systems. Energy 2011, 36 (6), 3691-3703.

(34) Walter, A.; Galdos, M. V.; Scarpare, F. V.; Leal, M. R. L. V.; Seabra, J. E. A.; Cunha, M. P.; Picoli, M. C.; Oliveira, C. O. F. Brazilian sugarcane ethanol: Developments so far and challanges for the future. WIREs Energy Environ. 2014, 3, 70-92.

(35) de Almeida, J. L.; Sampaio, P. H. Evaporator of vinasse concentration for distilleries in general. US Patent 20100055239 A1, 4 Mar. 2010.

(36) Humbird, D.; Davis, R.; Tao, L.; Kinchin, C.; Hsu, D.; Aden, A. Schoen, P.; Lukas, J.; Olthof, B.; Worley, M.; Sexton, D.; Dudgeon, D. Process Design and Economics for Biochemical Conversion of Lignocellulosic Biomass to Ethanol - dilute-acid pretreatment and enzimatic hydrolysis of corn stover; Technical Report NREL/TP-510047764; National Renewable Energy Laboratory, U.S. Department of Energy, Office of Energy Efficiency and Renewable Energy: 2011. http://www.nrel.gov/biomass/pdfs/47764.pdf (accessed Sept 20, 2014).

(37) Hsu, D. D.; Inman, D.; Heath, G. A.; Wolfrum, E. J.; Mann, M. K.; Aden, A. Life cycle environmental impacts of selected U.S. ethanol production and use pathways in 2022. Environ. Sci. Technol. 2010, 44 (13), 5289-5297.

(38) GREET (The Greenhouse Gases, Regulated Emissions, and Energy Use in Transportation Model). Versão 1.8c. Argonne National Latoratory, U.S. Department of Energy: 2007. https://greet.es.anl. gov/ (accessed Sept 20, 2014).

(39) Primo, K. R.; Salomon, K. R.; Teixeira, F. N.; Lora, E. S. Estudo de dispersão atmosférica dos óxidos de nitrogênio ( $\mathrm{NOx}$ ) emitidos durante a queima de bagaço em uma usina de açúcar. Biomassa Energia 2005, 2, 79-90.

(40) Boddey, R. M.; Soares, L. H. B.; Alves, B. J. R.; Urquiaga, S. Bioethanol Production in Brazil. In Biofuels, Solar and Wind as Renewable Energy Systems; Pimentel, D., Ed.; Springer Science+Business Media B.V.: 2008; Chapter 3, pp 321-356.

(41) Seabra, J. E. A. Avaliação técnico-econômica de opções para o aproveitamento integral da biomassa de cana no Brasil. Ph.D. Thesis, Universidade Estadual de Campinas, Campinas, 2008.

(42) Hassuani, S. J.; Leal, M. R. L. V.; Macedo, I. C. Biomass Power generation: sugarcane bagasse and trash; PNUD Brasil and Centro de Tecnologia Canavieira: Piracicaba, 2005. http://www.sucre-ethique. org/IMG/pdf/CTC_energy_-_biomass_1_.pdf (accessed Sept 20, 2014). 